\title{
The Influence of Green Space Patterns on Land Surface Temperature in Different Seasons: A Case Study of Fuzhou City, China
}

\author{
Liuqing Yang ${ }^{1,2}{ }^{\oplus}$, Kunyong Yu ${ }^{2,3}$, Jingwen Ai ${ }^{1,2}$, Yanfen Liu ${ }^{1,2}$, Lili Lin ${ }^{1,2} \oplus$, Lingchen Lin ${ }^{2,3}$ and Jian Liu ${ }^{1,2,3, *}$ \\ 1 College of Landscape Architecture, Fujian Agriculture and Forestry University, Fuzhou 350000, China;

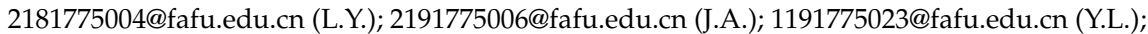 \\ lilil@g.clemson.edu (L.L.) \\ 2 University Key Lab for Geomatics Technology and Optimize Resource Utilization in Fujian Province, \\ Fujian Agriculture and Forestry University, Fuzhou 350000, China; yuyky@126.com (K.Y.); \\ lingchen_lin@fafu.edu.cn (L.L.) \\ 3 College of Forestry, Fujian Agriculture and Forestry University, Fuzhou 350000, China \\ * Correspondence: fjliujian@fafu.edu.cn; Tel.: +86-136-0598-5226
}

check for updates

Citation: Yang, L.; Yu, K.; Ai, J.; Liu, Y.; Lin, L.; Lin, L.; Liu, J. The Influence of Green Space Patterns on Land Surface Temperature in Different Seasons: A Case Study of Fuzhou City, China. Remote Sens. 2021, 13 , 5114. https://doi.org/10.3390/ rs13245114

Academic Editors: Yuji Murayama and Ruci Wang

Received: 24 October 2021

Accepted: 13 December 2021

Published: 16 December 2021

Publisher's Note: MDPI stays neutral with regard to jurisdictional claims in published maps and institutional affiliations.

Copyright: (C) 2021 by the authors Licensee MDPI, Basel, Switzerland. This article is an open access article distributed under the terms and conditions of the Creative Commons Attribution (CC BY) license (https:/ / creativecommons.org/licenses/by/ $4.0 /)$.
Abstract: Background: Urban green space (UGS) has been shown to play an important role in mitigating urban heat island (UHI) effects. In the context of accelerating urbanization, a better understanding of the landscape pattern mechanisms affecting the thermal environment is important for the improvement of the urban ecological environment. Methods: In this study, the relationship between land surface temperature (LST) and the spatial patterns of green space was analyzed using a bivariate spatial autocorrelation and spatial autoregression model in three seasons (summer, transition season (spring), and winter) with different grid scales in Fuzhou city. Results: Our results indicated that the LST in Fuzhou City has a significant spatial autocorrelation. The percentage of landscape and patch density area were negatively correlated with surface temperature. The results of our indicators differed according to the season, with population density and distance to the water indicators not being significant in the winter. The coefficient of determination was higher at the $510 \mathrm{~m}$ grid scale on this study's scale. Conclusion: This study extends our understanding on the influence of UHI effects after accounting for different seasonal and spatial scale factors. It also provides a reference for urban planners to mitigate heat islands in the future.

Keywords: land surface temperature; greenspace spatial patterns; landscape metrics; spatial autoregressive model; seasonal variation

\section{Introduction}

China is currently experiencing rapid urbanization, with the urbanization rate expected to reach $70 \%$ by 2030 . As urbanization accelerates, the subsequent expansion of roads and buildings has led to the reduction of green space, resulting in a significant increase in the temperature of the city relative to the peripheral suburbs, a phenomenon also known as the urban heat island (UHI) effect [1]. Not only does the UHI effect affect the local and regional climate [2], it also affects water resources, air quality [3,4], the growth of plants [5], biodiversity, and the ecosystem in general [6]. It also has an adverse impact on the health of urban residents [7,8]. Developing effective adaptation measures and mitigation strategies for UHI effect is thus a common challenge that urban planners and climatologists are currently facing.

Rapid urbanization has significantly affected land cover characteristics. This change affects the characteristics of surface radiation, heat, and water in urban areas, and increases the urban surface temperature. On the one hand, remote sensing collected by satellites or airborne platforms has been proven effective in evaluating large-scale and local-scale land surface temperature (LST) [9]. By monitoring the relationship between the spatial 
change of LST and UHI combined with satellite images, it is found that impervious surfaces and urban green space (UGS) are highly related to LST. The average LST of impervious surfaces is $4-6{ }^{\circ} \mathrm{C}$ higher than that of green space, which indicates that urban expansion is the fundamental reason behind the UHI effect [10-15]. At the same time, urbanization has led to land use/land cover (LULC) change on the surface, while the transformation of forest land for commercial land use intensified the change in surface temperature and humidity [16,17].

UGS has been proven to be an important measure for alleviating the UHI effect [12], given that increasing vegetation coverage in urban areas has been proven to effectively reduce LST [18-20]. As such, many scholars have carried out research on the shape [21], area, structure, composition, and configuration of green space [22]. It has been found that the connectivity [23], complexity [24], and fragmentation of greenfield patches are all strongly correlated with LST [25-27]. It is confirmed that the structure and configuration of green space can effectively reduce urban temperature by rational optimization [28].

As a fast-growing city in China, Fuzhou's rapid urban expansion has led to a large reduction in wetlands and woodlands, which has earned Fuzhou the title of a "burning stove" in recent years [18]. Therefore, studying the spatial distribution and composition of UGS in Fuzhou City and analyzing the changes in its landscape patterns can guide us toward alleviating the urban heat island effect. However, the cooling effect of the UGS spatial pattern differs regionally [29]. Thus, further research is needed to optimize the effect of UGS on UHI and clarify the effect of UGS on UHI mitigation in different cities. Considering the changes in UGS, the relationship between UGS landscape patterns and LST is mostly analyzed via correlation or linear regression [20,30], which ignores the spatial heterogeneity of the two. Moreover, due to the difference in landscape patterns, the relationship between landscape patterns of different geographical environments and LST is not consistent $[12,31]$. Therefore, while considering the spatial patterns of green space by combining spatial autocorrelation and spatial regression models, this paper analyzes the spatial relationship between green space landscape patterns and LST in different seasons and scales in Fuzhou, while adding further discussion on the impact mechanism of green space on the thermal environment.

\section{Methods}

\subsection{Study Area and Data Source}

Fuzhou is the capital of Fujian Province in China, which is located at $25^{\circ} 15^{\prime}-26^{\circ} 39^{\prime}$ $\mathrm{N}, 118^{\circ} 08^{\prime}-120^{\circ} 31^{\prime} \mathrm{E}$, and has a subtropical monsoon climate. The urbanization process of Fuzhou has been particularly obvious in recent years. According to data from the Fuzhou Bureau of Statistics, by the end of 2017, the population of Fuzhou was 7.21 million, with 5.105 million urban residents; the urbanization rate of Fuzhou had already exceeded 70 percent (70.8 percent). The conversion of water bodies and UGS into major built-up areas amounted to 13.3 and $20.2 \mathrm{~km}^{2}$. From 1985 to 2015, the area of built-up areas doubled. Large UGS losses during urbanization are the main impact of the urban thermal environment [18,32]. The study area covers a total of $1448.479 \mathrm{~km}^{2}$ (Figure 1).

Fuzhou has a subtropical monsoon climate, which is marked by longer summers and shorter winters. Spring starts in March and ends in June, while autumn starts in October and ends in November. After analyzing the temperature changes in Fuzhou from 2000-2020 (Figure 2), we found that the temperature distributions in spring and autumn were relatively similar, and that there was little difference in temperature between April and May in spring, and October and November in autumn. Therefore, the study divided the seasons in Fuzhou into three types: summer, transitional seasons, and winter [33-35]. Landsat8 image data (11 December 2019, 16 March 2020, and 22 July 2020) for three different periods were selected from the USGS (https:/ / espa.cr.usgs.gov/index/ accessed on 18 March 2021) and radiometric and geometric corrections were applied [36]. Based on the atmospheric correction method, LST was retrieved from the thermal band of Landsat8 images to characterize the LST of different seasons. 

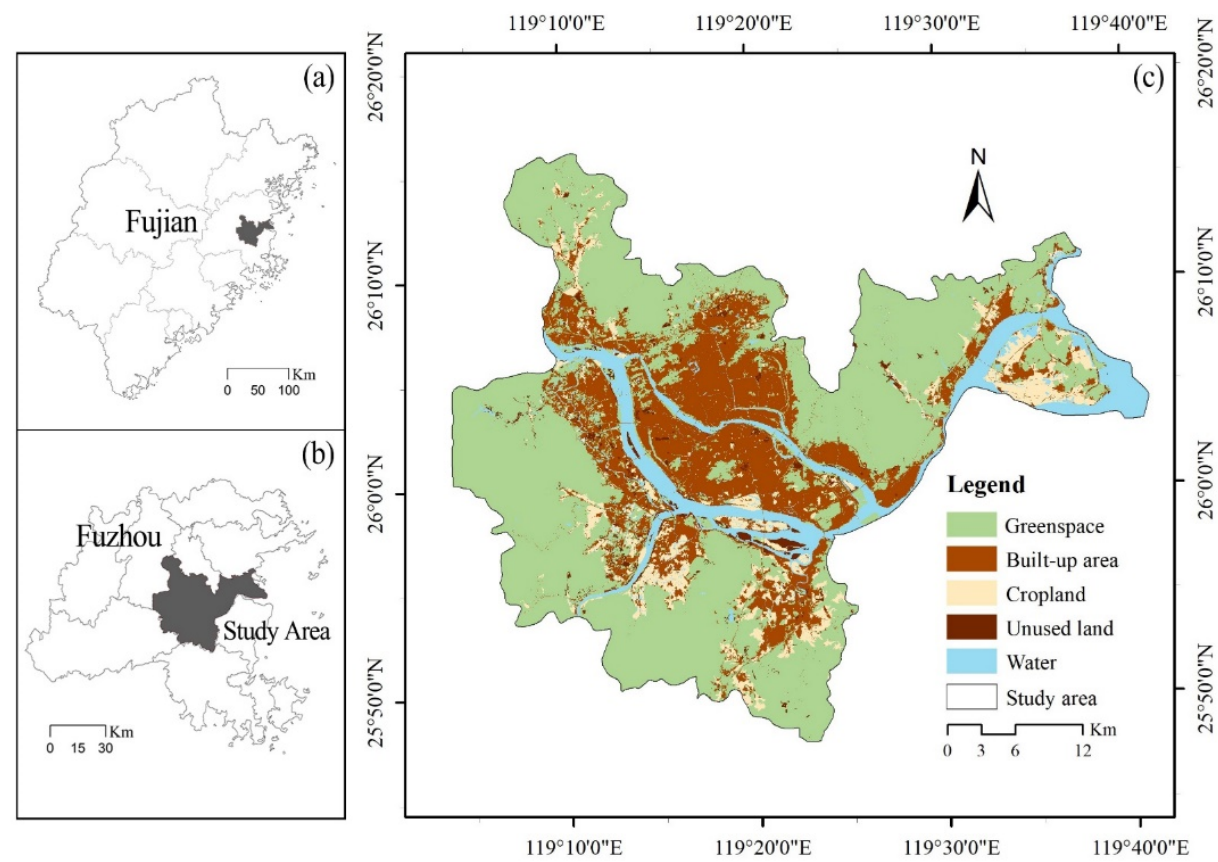

Figure 1. Study area: (a) Fujian Province, China; (b) Fuzhou City, Fujian Province; (c) the land classification of Fuzhou City in this study area.

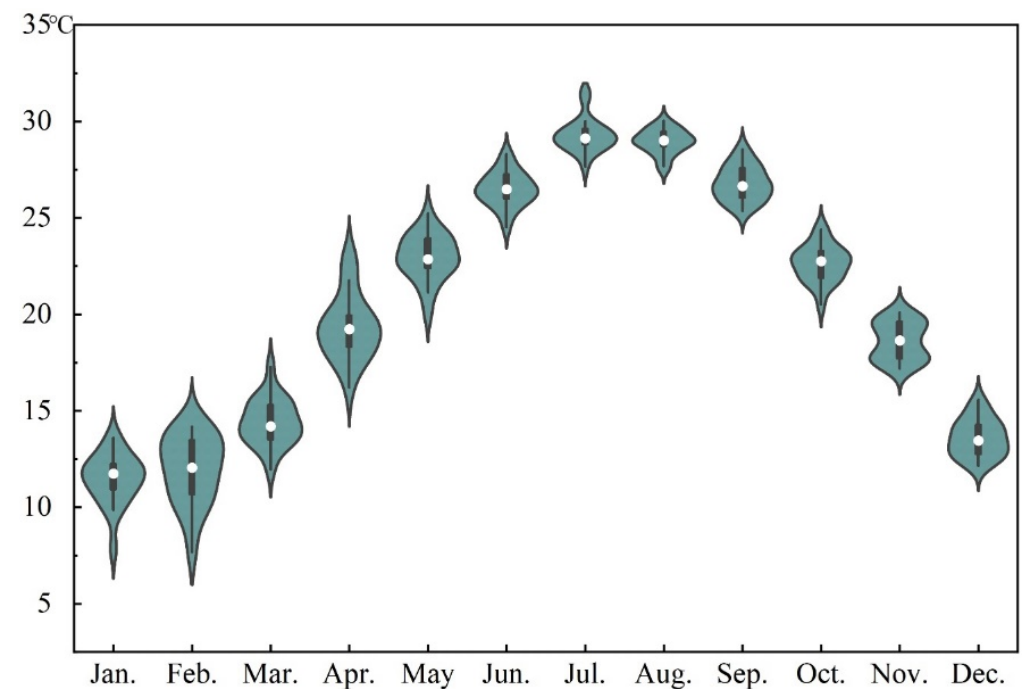

Figure 2. Violin plot of the monthly average air temperature in Fuzhou City during 2000-2020.

Land use data were obtained using the 2018 Gaofen-1 satellite (GF-1) image, which has a panchromatic resolution of $2 \mathrm{~m}$ and a multispectral resolution of $8 \mathrm{~m}$ [37]. Using eCognition software (Definiens Imaging, Inc., Munich, Germany), five main landscape types were extracted based on an object-oriented classification approach-green space, built-up area, water body, cropland, and unused land-and combined with high-resolution historical images from Google Earth ${ }^{\mathrm{TM}}$, they were used as a reference layer to assess classification accuracy for all land types. The classification accuracy assessment was calculated based on a confusion matrix of 100 randomly selected points, with an overall classification accuracy of $88.19 \%$. At the same time, the results of land use classification were further used to analyze the landscape metrics of UGS. 


\subsection{Retrieving Land-Surface Temperature (LST)}

This research is based on the atmospheric correction method, and the Landsat8 TIRS was used to retrieve the surface temperature with a data accuracy of $30 \mathrm{~m} \times 30 \mathrm{~m}$.

$$
L_{\lambda}=\left[\varepsilon \mathrm{B}\left(T_{s}\right)+(1-\varepsilon) L_{d}\right] \tau+L_{\mu}
$$

In Equation (1), $L_{\mu}$ is the upwelling radiance, $L_{d}$ is the downwelling radiance, $\varepsilon L_{\lambda}$ is the top-of-atmosphere (TOA) radiance, where $\varepsilon$ is the surface emissivity, $\mathrm{B}\left(T_{s}\right)$ is the black body heat radiation brightness, and $\tau$ is the transmittance of the atmosphere in the thermal infrared band. Thus, the radiance of a black body with a temperature of $\mathrm{T}$ in the thermal infrared band $\mathrm{B}\left(T_{S}\right)$ is:

$$
\mathrm{B}\left(T_{s}\right)=\frac{L_{\lambda}-L_{\mu}-\tau(1-\varepsilon) L_{d}}{\tau \varepsilon}
$$

$T_{S}$ is the true surface temperature (LST) $\left({ }^{\circ} \mathrm{C}\right)$, which can be obtained by the function of Planck's formula:

$$
T_{S}=\frac{K_{2}}{\ln \left(K_{1} / \mathrm{B}\left(T_{s}\right)+1\right)}
$$

For Landstat $8, K_{1}=774.89 \mathrm{~W} /\left(\mathrm{m}^{2} \cdot \mu \mathrm{m} \cdot \mathrm{sr}\right), K_{2}=1321.08 \mathrm{~K}$.

\subsection{Influencing Factors Selection}

The landscape metrics can effectively quantify the structural composition and spatial configuration characteristics of the patch [38], given that studies have proven landscape composition and configuration to have a significant impact on LST [39]. Based on the results of previous studies, six commonly used landscape indicators were selected as explanatory variables for LST changes [30]. To account for the correlation between the various landscape metrics, to fully reflect the landscape pattern of green space, and to avoid potential correlations caused by redundant metrics, we selected percentage of landscape (PLAND), patch density (PD), edge density (ED), aggregation index (AI), mean patch size (AREA_MN), and mean shape index (SHAPE_MN) as our key indicators [40] to analyze the relationship between green space landscape pattern and LST. These indicators reflect the main characteristics of green space patterns. Generally, PLAND and AREA_MN represent the patch area, PD and ED are indicator density and patch boundary, while SHAPE_MN is the patch shape index and AI represents the spread of landscape patches.

We used the grid analysis method to analyze the green landscape pattern metrics using the FRAGSTATS 4.2 software [31]. However, the appropriate grid scale is still argued in the literature, and previous studies have proved that the green space cooling effect is scaledependent [41], while the optimal scale varies depending on study area [12]. To explore the suitable grid scale in Fuzhou, we applied four grid scales: $360 \mathrm{~m} \times 360 \mathrm{~m}, 510 \mathrm{~m} \times 510 \mathrm{~m}$, $720 \mathrm{~m} \times 720 \mathrm{~m}$, and a $960 \mathrm{~m} \times 960 \mathrm{~m}$ grid scale (all grid scales are integer multiples of $30 \mathrm{~m}$ accuracy of landsat8 images) [25,42-44]. By extracting the green landscape metrics of each grid, a grid image of each green landscape metric were obtained. We then used ArcGIS 10.2 (ESRI, Redlands, CA, USA) software to calculate the average LST and landscape metrics for each grid. We normalize the indicator results before analysis. Considering the impact of the water bodies and population density on LST [11,45-47], we also added closest distance to a water (water_distance) [17] and population density as research variables (https:/ / www.worldpop.org/ accessed on 30 June 2021). The accuracy of the population density map was $100 \mathrm{~m} \times 100 \mathrm{~m}$ (Table 1). We applied the Pearson correlation to check the strength of the association between LST and each variable indicator. 
Table 1. Descriptions of the variables used in this study [48].

\begin{tabular}{|c|c|c|c|}
\hline Variables & Description & Formula & Unit \\
\hline $\begin{array}{c}\text { Percentage of } \\
\text { landscape (PLAND) }\end{array}$ & $\begin{array}{l}\text { The proportional abundance of } \\
\text { each patch type in the } \\
\text { landscape within an analysis } \\
\text { unit. }\end{array}$ & $\begin{array}{c}\text { PLAND }=p_{i}= \\
\frac{\sum_{j=1}^{n} a_{i j}}{A} * 100\end{array}$ & Percent \\
\hline Patch density (PD) & $\begin{array}{l}\text { Density of landscape patches } \\
\text { within an analysis unit, reflects } \\
\text { the degree of fragmentation } \\
\text { and spatial heterogeneity of } \\
\text { landscape patches. }\end{array}$ & $\begin{array}{c}P D= \\
\frac{N_{i}}{A}(10000) *(100)\end{array}$ & $\mathrm{n} / \mathrm{km}^{2}$ \\
\hline Edge density (ED) & $\begin{array}{l}\text { The total perimeter of } \\
\text { landscape patches per ha } \\
\text { within an analysis unit, reflects } \\
\text { the degree of fragmentation of } \\
\text { the patch. }\end{array}$ & $E D=\sum_{k=1}^{m} e_{i k} \times \frac{10000}{A}$ & $\mathrm{~m} / \mathrm{ha}$ \\
\hline $\begin{array}{l}\text { Aggregation Index } \\
\text { (AI) }\end{array}$ & $\begin{array}{l}\text { Aggregating degree of the } \\
\text { corresponding patches within } \\
\text { an analysis unit. }\end{array}$ & $A I=\left|\frac{g_{i i}}{\max -g_{i i}}\right| * 100$ & Percent \\
\hline $\begin{array}{l}\text { Mean patch area } \\
\text { (AREA_MN) }\end{array}$ & $\begin{array}{l}\text { The average area of landscape } \\
\text { patches within an analysis unit. }\end{array}$ & $\begin{array}{l}\text { AREA_MN }= \\
\frac{1}{10000 \times n} \times \sum_{i=1}^{n} a_{i j}\end{array}$ & Hectares \\
\hline $\begin{array}{l}\text { Mean patch shape } \\
\text { index (SHAPE_MN) }\end{array}$ & $\begin{array}{l}\text { The average shape index of } \\
\text { landscape patches within an } \\
\text { analysis unit, for reflecting the } \\
\text { complexity of individual patch } \\
\text { shapes. }\end{array}$ & $\begin{array}{l}\text { SHAPE_MN }= \\
\quad \frac{1}{n} \times \frac{0.25 p_{i j}}{\sqrt{a_{i j}}}\end{array}$ & unitless \\
\hline Water_distance & $\begin{array}{l}\text { Analyze the Euclidean distance } \\
\text { of each unit to the water } \\
\text { bodies. }\end{array}$ & & $\mathrm{Km}$ \\
\hline Population density & $\begin{array}{l}\text { The population density within } \\
\text { an analysis unit. }\end{array}$ & & People/km \\
\hline
\end{tabular}

A, total landscape area $\left(\mathrm{m}^{2}\right) ; a_{i j}$, area $\left(\mathrm{m}^{2}\right)$ of patch $i j ; N_{i}$, number of patches in the landscape of patch type (class) $n$, number of patches $p_{i}$, proportion of the landscape occupied by patch type (class) $i ; e_{i k}$, total length (m) of edge in landscape involving patch type (class) $i ; p_{i j}$, perimeter $(\mathrm{m})$ of patch $i j ; g_{i i}$, number of like adjacencies (joins) between pixels of patch type (class) $i$ based on the single-count method; max- $g_{i i}$, maximum number of like adjacencies (joins) between pixels of patch type (class) $i$ based on the single-count method.

\subsection{Spatial Autocorrelation and Spatial Autoregressive Model}

Spatial autocorrelation analysis reveals whether the variables are spatially correlated, and the degree of autocorrelation [49]. Spatial autocorrelation includes global spatial autocorrelation and local spatial autocorrelation, and here we use global Moran's I (the spatial correlation of the whole study area) and local indicators of spatial association (LISA) (the spatial correlation of each spatial unit and its neighboring units for a certain attribute) to describe the above results [50,51]. Moran's I values range from -1 to 1 , with negative values indicating negative spatial autocorrelation, and positive values indicating positive spatial autocorrelation. LISA plots depict the results of five scenarios: clusters of high values (high-high), clusters of low values (low-low), outliers where high values are surrounded by low values (high-low), and outliers where low values are surrounded by high values (low-high) and have no significant local autocorrelation (not-significant). It determines the degree of spatial clustering present in the data ( $p$-value). Additionally, the bivariate spatial autocorrelation analysis was used to analyze the spatial correlation of different variables with LST [52]. The GeoDa (v.1.14.0; Luc Anselin, AZ, USA) software was used for the above-mentioned spatial correlation analysis. 
The formula for global spatial autocorrelation can be expressed as:

$$
I=\frac{n}{S_{0}} \frac{\sum_{i=1}^{n} \sum_{j=1}^{n} w_{i, j} z_{i} z_{j}}{\sum_{i=1}^{n} z_{i}^{2}}
$$

where $n$ is the total number of spatial units, $z_{i}$ is the attribute of element $i$ with its mean $\left(x_{i}-\bar{x}\right), w_{i, j}$ is the spatial weight value between $i, j$, and $S_{0}$ is the aggregation of all spatial weights.

$$
S_{0}=\sum_{i=1}^{n} \sum_{j=1}^{n} w_{i j}
$$

The $z_{x}$ score for the statistic is given by:

$$
z_{x}=\frac{I-E[I]}{\sqrt{V[I]}}
$$

where

$$
\begin{gathered}
E[I]=\frac{-1}{(n-1)} \\
V[I]=E\left[I^{2}\right]-E[I]^{2}
\end{gathered}
$$

A traditional ordinary least squares (OLS) model was employed to examine the effect of each variable on the change in LST.

$$
y=X \beta+u
$$

where $X$ is the matrix of explanatory variables, $\beta$ denotes a vector of slopes, and $u$ represents a vector of random error terms.

Spatial lag model (SLM):

$$
y=\rho W y+X \beta+u
$$

where $\rho$ is a spatial autocorrelation parameter, $W$ is the spatial weight matrix, $W y$ is the spatial lag operator, and $\beta$ is the unknown coefficient vector.

Spatial error model (SEM):

$$
y=X \beta+\gamma W \varepsilon+\delta
$$

where $\gamma$ is the spatial autocorrelation parameter, $W \varepsilon$ denotes the spatial weight matrix, and $\delta$ represents a vector of the error terms.

The spatial error model and the spatial lag model were determined using Lagrangian multiplier diagnostics (LM) $[36,44]$. The LM and robust LM values of the SEM model are larger than that of SLM, indicating that SEM performed better than SLM. Results show that the spatial error model was suitable for the data in this study (Table A1).

\section{Results}

\subsection{Spatial Characteristics of LST}

In general, the spatial distribution characteristics of LST in Fuzhou during different seasons tend to be consistent. High-temperature areas were mainly concentrated in the city center (Figure 3). As Fuzhou is surrounded by mountains on three sides (Gushan Mountain to the east, Wuhu Mountain to the south, and Qishan Mountain to the west), the vegetation coverage is high and the forests are relatively abundant. Thus, low-temperature areas mainly surround the urban areas. In summer, the temperature in Fuzhou can reach above $50{ }^{\circ} \mathrm{C}$ (with an average of $43^{\circ} \mathrm{C}$ ) (Table 2), which is quite different from the other two seasons and can seriously affect daily travel [53]. 


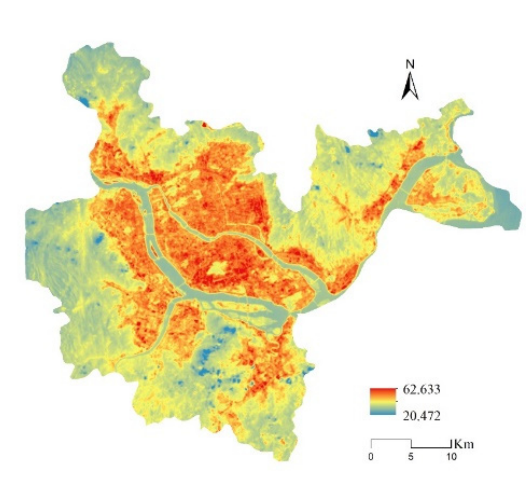

(a)

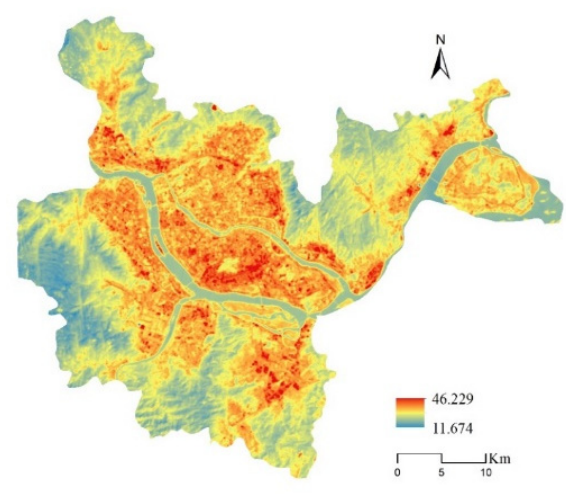

(b)

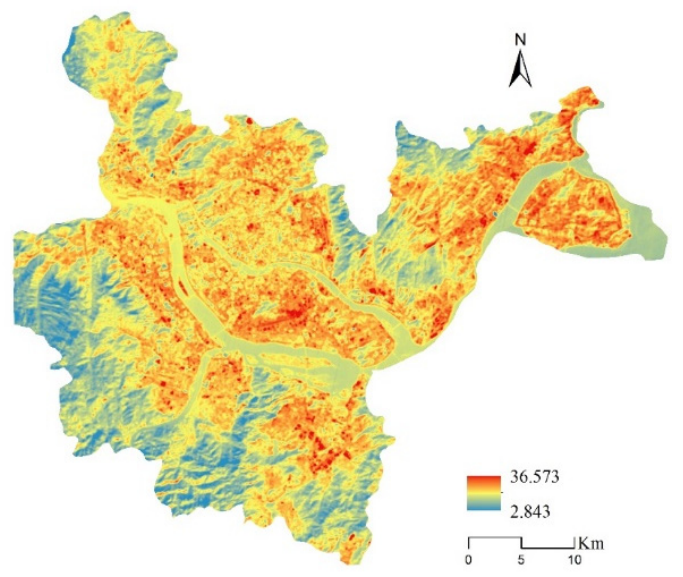

(c)

Figure 3. The three images represent the spatial distribution of land surface temperature $\left(\mathrm{LST},{ }^{\circ} \mathrm{C}\right)$ in $(\mathbf{a})$ summer, $(\mathbf{b})$ transitional season, and (c) winter, respectively.

Table 2. Temperature in different seasons.

\begin{tabular}{ccccccc}
\hline Season & Data Date & Local Time & Minimum & Maximum & Average & Std. Dev. \\
\hline Summer & 22 July 2020 & $02: 32: 25$ & 20.473 & 62.633 & 43.417 & 5.556 \\
Transition season & 16 March 2020 & $02: 32: 22$ & 11.674 & 46.229 & 22.305 & 3.168 \\
Winter & 11 December 2019 & $02: 32: 49$ & 2.843 & 36.573 & 18.225 & 1.901 \\
\hline
\end{tabular}

Through the analysis of the study area, the LST distribution of global Moran's I is positively autocorrelated (Table 3). The overall distribution of LST and the spatial autocorrelation of LST were also significant at the 0.01 level, indicating that the spatial distribution of LST exhibited aggregation. With an increase in the grid scale, the larger the scale, the lower the correlation to a certain extent. At the same time, the global Moran's I of LST in summer and the transition season was greater than that in winter. It can be seen from (Figure A1) that the spatial aggregation distribution trends of all scales in the study area are basically the same. The low-low cluster (L-L) is distributed in the forest areas to the west, east, and north, while the proportion of high-high clusters $(\mathrm{H}-\mathrm{H})$ is relatively large and distributed mostly in the urban center and a little to the south. With a decrease in temperature, the L-L distribution in the urban area decreased. The distribution proportions of the high-low cluster (H-L) and low-high cluster (L-H) were small and sporadic. In winter, $\mathrm{H}-\mathrm{H}$ accumulation in the urban center decreased significantly, but increased in the east. The distribution of L-L increased with a decrease in temperature, especially in the south. 
Table 3. Global Moran's I (Equation (4)) of land surface temperature (LST).

\begin{tabular}{ccccc}
\hline \multirow{2}{*}{ Scale (m) } & Global Moran's $I$ & & & \\
\cline { 2 - 5 } & Summer & Transition Season & Winter & $p$-Value \\
\hline $360 \mathrm{~m}$ & 0.766 & 0.773 & 0.653 & $<0.01$ \\
$510 \mathrm{~m}$ & 0764 & 0772 & 0668 & $<0.01$ \\
$720 \mathrm{~m}$ & 0.664 & 0.673 & 0.546 & $<0.01$ \\
$960 \mathrm{~m}$ & 0.620 & 0.644 & 0.548 & $<0.01$ \\
\hline
\end{tabular}

\subsection{LST and UGS Spatial Pattern Analysis}

\subsubsection{Analysis of the Spatial Pattern of Green Space}

By comparing the cities around Fuzhou [54], the patch density (PD) and edge density (ED) in Fuzhou were higher than the surrounding cities, and the mean patch area (AREA_MN) value was lower. The higher the patch density, the higher the fragmentation of the landscape; the higher the edge density, the lower the aggregation of patches at the edge of the landscape, while the small average patch area indicates that there are many small green areas with a certain degree of fragmentation in the Fuzhou UGS. Meanwhile, the global Moran's I is also greater than 0.7 (Table 4), thus indicating that the green space has obvious spatial aggregation.

Table 4. Green space landscape metrics and global spatial autocorrelation analysis.

\begin{tabular}{|c|c|c|c|c|c|c|}
\hline \multicolumn{6}{|c|}{ Landscape Metrics } & \multirow{2}{*}{ Moran's 1} \\
\hline PLAND (\%) & $\mathrm{PD}\left(\mathrm{n} / \mathrm{km}^{2}\right)$ & $\mathrm{ED}(\mathrm{m} / \mathrm{ha})$ & AI (\%) & AREA_MN (ha) & SHAPE_MN & \\
\hline 58.379 & 33.869 & 65.510 & 82.582 & 10.222 & 1.197 & 0.869 \\
\hline
\end{tabular}

\subsubsection{Bivariate Analysis of Green Space Landscape Pattern Index and LST}

Pearson's correlation coefficient and bivariate spatial autocorrelation analysis showed that the relationship between each indicator and LST was more significant in summer and transition seasons than in winter (Figure 4). The correlations of PLAND, AI, AREA_MN, and water_distance were all negative. Among the negative indicators, PLAND and AREA_MN were more strongly correlated with LST, indicating that the increase in the proportion of green patches can have a cooling effect. ED, SHAP_MN, and population density were positive numbers. This indicates that the increase of patch edge density leads to the fragmentation of green areas. Under different grid scales, the correlation between the positive indexes SHAPE_MN and ED increases with an increase in the grid scale, while the negative index AI is the opposite. The larger the grid, the lower the correlation. There was no strong correlation between PD and spatial autocorrelation (see Figure $4 \mathrm{~b}$ ).

\subsubsection{Spatial Autoregressive Analysis}

Spatial autoregressive analysis was carried out using LST as the dependent variable. At the same time, before performing spatial regression analysis, all indicators passed the collinearity test with variance inflation factor (VIF) values less than 10, indicating that there was no problem with collinearity among the indicators.

From the results of the OLS analysis (Table 5), the correlation of the overall indicators is the highest in the transition season and lowest in winter. The contribution of PLAND and PD to LST cooling is larger (especially PLAND), while ED, AI, and population density are obviously positive. At the same time, the correlation of PLAND decreased from summer to winter, while PD remained relatively stable. In terms of positive correlation indicators, the LST interpretation rates of ED, AI, and population density increased with an increase in temperature. Water distance is positively correlated in summer and transition seasons, while negatively correlated in winter. AREA_MN loses explanatory significance as the temperature decreases. On the grid scale, as the grid scale increases, the fit of each index (R2) in different seasons grows higher under the OLS model. 

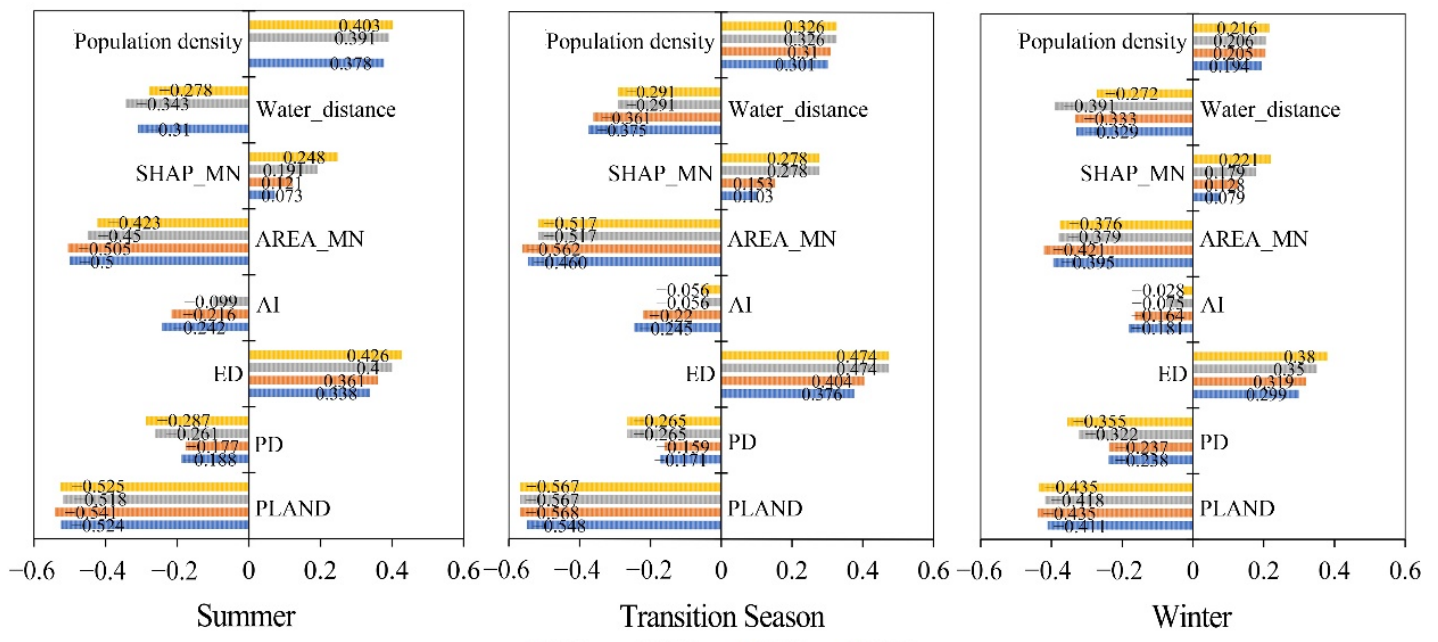

(a)
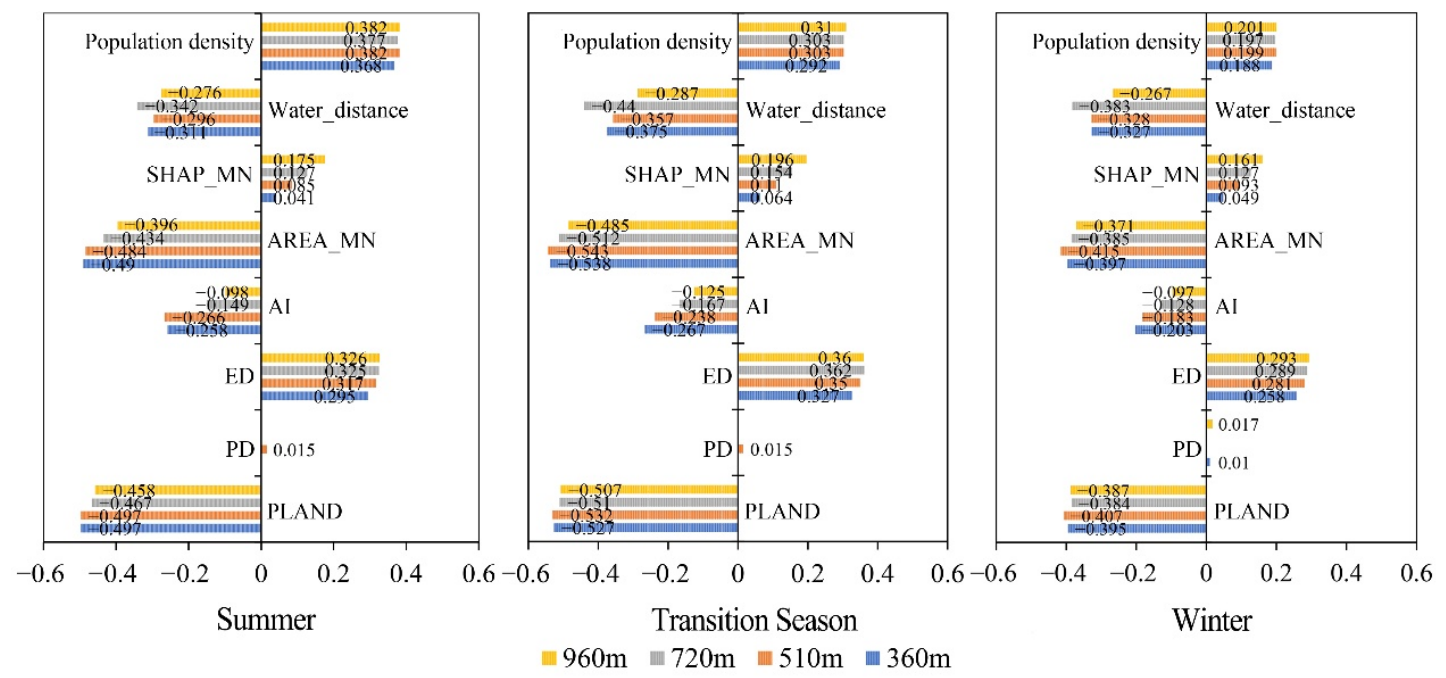

(b)

Figure 4. Pearson correlation analysis at different scales and bivariate spatial autocorrelation. Values without significant correlation were excluded from the graph. (a) Pearson correlation analysis; (b) bivariate spatial autocorrelation.

However, it was found through the results that the residuals of the OLS model Moran's I had significant spatial clustering (Table A1), and the traditional OLS regression model may have ignored the spatial correlation of the indicators, so the SEM model was used for further analysis (Table 6).

Specifically, the coefficients of ED, AI were significantly positive. The coefficients for PLAND and PD were significantly negative. SHAPE_MN was not statistically significant. The correlation of overall indicators was better in the summer and transition season than in the winter. Under the standardized coefficient, the indexes of PLAND and PD make a great contribution to the reduction of LST; with the increase in grid scale, the effect of index on LST is enhanced. At the same time, with the increase in scale, the correlation between AREA_MN, water_distance, population density, and LST disappeared. From the fitting results, the fitting effect $\left(\mathrm{R}^{2}\right)$ of the $510 \mathrm{~m}$ scale is higher than that of the other scales in this study. Compared with the OLS model, the interpretation degree of the SEM index for seasonal changes is lower, but the overall fitting effect of the index is better than that of OLS. 
Table 5. Results from the ordinary least squares (OLS) multiple linear regressions.

\begin{tabular}{|c|c|c|c|c|c|c|c|c|c|c|c|}
\hline Season & Scale (m) & PLAND & PD & ED & AI & AREA_MN & SHAPE_MN & Water_Distance & Population Density & AIC & $\mathbf{R}^{2}$ \\
\hline \multirow{4}{*}{ Summer } & $360 \mathrm{~m}$ & $\begin{array}{l}-0.081^{* * *} \\
(-0.610)\end{array}$ & $\begin{array}{c}-0.002^{* * *} \\
(-0.181)\end{array}$ & $\begin{array}{c}0.014^{* * *} \\
(0.250)\end{array}$ & $\begin{array}{c}0.025^{* * *} \\
(0.155)\end{array}$ & $\begin{array}{c}0.075^{* * *} \\
(0.077)\end{array}$ & $\begin{array}{c}-0.179 \\
(-0.019)\end{array}$ & $\begin{array}{c}0.000 * * * \\
(0.058)\end{array}$ & $\begin{array}{c}0.022 * * * \\
(0.215)\end{array}$ & $67,392.8$ & 0.424 \\
\hline & $510 \mathrm{~m}$ & $\begin{array}{l}-0.076^{* *} \\
(-0.585)\end{array}$ & $\begin{array}{c}-0.003^{* * *} \\
(-0.221)\end{array}$ & $\begin{array}{c}0.017^{* * *} \\
(0.289)\end{array}$ & $\begin{array}{c}0.024^{* * *} \\
(0.143)\end{array}$ & $\begin{array}{c}0.028 * * \\
(0.057)\end{array}$ & $\begin{array}{c}-0.220 \\
(-0.022)\end{array}$ & $\begin{array}{c}0.000^{* * *} \\
(0.077)\end{array}$ & $\begin{array}{c}0.022^{* * *} \\
(0.217)\end{array}$ & $34,568.3$ & 0.459 \\
\hline & $720 \mathrm{~m}$ & $\begin{array}{l}-0.077 * * \\
(-0.562)\end{array}$ & $\begin{array}{c}-0.001 * * * \\
(-0.226)\end{array}$ & $\begin{array}{c}0.017 * * * \\
(0.256)\end{array}$ & $\begin{array}{c}0.039 * * * \\
(0.193)\end{array}$ & $\begin{array}{l}0.016^{*} \\
(0.061)\end{array}$ & $\begin{array}{l}-0.022 \\
0.000^{* *}\end{array}$ & $\begin{array}{c}0.000 * * \\
(0.051)\end{array}$ & $\begin{array}{c}0.024^{* * *} \\
(0.219)\end{array}$ & $17,156.5$ & 0.474 \\
\hline & $960 \mathrm{~m}$ & $\begin{array}{l}-0.073^{* *} \\
(-0.533)\end{array}$ & $\begin{array}{l}-0.001^{* * *} \\
(-0.241)\end{array}$ & $\begin{array}{c}0.019 \text { *** } \\
(0.264)\end{array}$ & $\begin{array}{c}0.056^{* * *} \\
(0.238)\end{array}$ & $\begin{array}{l}0.008^{*} \\
(0.056)\end{array}$ & $\begin{array}{c}-0.177 \\
(-0.015)\end{array}$ & $\begin{array}{c}0.000 \\
(0.013)\end{array}$ & $\begin{array}{c}0.024^{* * *} \\
(0.223)\end{array}$ & 9729.38 & 0.551 \\
\hline \multirow{4}{*}{$\begin{array}{l}\text { Transition } \\
\text { Season }\end{array}$} & $360 \mathrm{~m}$ & $\begin{array}{c}-0.040^{* * * *} \\
(-0.540)\end{array}$ & $\begin{array}{c}-0.001^{* * *} \\
(-0.169)\end{array}$ & $\begin{array}{c}0.007^{* * * *} \\
(0.235)\end{array}$ & $\begin{array}{c}0.012 * * * \\
(0.131)\end{array}$ & $\begin{array}{c}-0.008 \\
(-0.014)\end{array}$ & $\begin{array}{c}0.102 \\
(0.019)\end{array}$ & $\begin{array}{c}0.000 * \\
(-0.018)\end{array}$ & $\begin{array}{c}0.007^{* * * *} \\
(0.117)\end{array}$ & 53,706 & 0.432 \\
\hline & $510 \mathrm{~m}$ & $\begin{array}{c}-0.038^{* * * *} \\
(-0.526)\end{array}$ & $\begin{array}{l}-0.002^{* * *} \\
(-0.207)\end{array}$ & $\begin{array}{c}0.009 * * * \\
(0.277)\end{array}$ & $\begin{array}{c}0.012 * * * \\
(0.123)\end{array}$ & $\begin{array}{c}-0.011^{*} \\
(0.040)\end{array}$ & $\begin{array}{c}0.040 \\
(0.007)\end{array}$ & $\begin{array}{c}0.000 \\
(0.008)\end{array}$ & $\begin{array}{c}0.006^{* * *} \\
(0.112)\end{array}$ & $27,337.2$ & 0.472 \\
\hline & $720 \mathrm{~m}$ & $\begin{array}{c}-0.036^{* * *} \\
(-0.474)\end{array}$ & $\begin{array}{c}-0.001 * * * \\
(-0.212)\end{array}$ & $\begin{array}{c}0.009 * * * \\
(0.236)\end{array}$ & $\begin{array}{c}0.019 * * * \\
(0.167)\end{array}$ & $\begin{array}{l}-0.006 \\
(0.041)\end{array}$ & $\begin{array}{c}0.197 \\
(0.032)\end{array}$ & $\begin{array}{c}0.000^{* * *} \\
(0.070)\end{array}$ & $\begin{array}{c}0.007^{* * *} \\
(0.114)\end{array}$ & 13,485 & 0.495 \\
\hline & $960 \mathrm{~m}$ & $\begin{array}{l}-0.040^{* * *} \\
(-0.533)\end{array}$ & $\begin{array}{l}-0.001^{* * *} \\
(-0.226)\end{array}$ & $\begin{array}{c}0.010^{* * *} \\
(0.258)\end{array}$ & $\begin{array}{c}0.030 * * * \\
(0.231)\end{array}$ & $\begin{array}{l}-0.006^{*} \\
(-0.068)\end{array}$ & $\begin{array}{c}-0.007 \\
(-0.001)\end{array}$ & $\begin{array}{c}0.000 \\
(0.019)\end{array}$ & $\begin{array}{c}0.007^{* * *} \\
(0.113)\end{array}$ & 7571.76 & 0.538 \\
\hline \multirow{4}{*}{ Winter } & $360 \mathrm{~m}$ & $\begin{array}{c}-0.019 * * * \\
(-0.425)\end{array}$ & $\begin{array}{c}-0.001^{* * *} \\
(-0.231)\end{array}$ & $\begin{array}{c}0.004^{* * *} \\
(0.218)\end{array}$ & $\begin{array}{c}0.004^{* * *} \\
(0.081)\end{array}$ & $\begin{array}{l}0.022 * * \\
(0.065)\end{array}$ & $\begin{array}{c}0.034 \\
(0.010)\end{array}$ & $\begin{array}{l}0.000^{* * *} \\
(-0.076)\end{array}$ & $\begin{array}{c}0.002 * * * \\
(0.049)\end{array}$ & $45,041.6$ & 0.290 \\
\hline & $510 \mathrm{~m}$ & $\begin{array}{c}-0.018^{* * *} \\
(-0.407)\end{array}$ & $\begin{array}{l}-0.002^{* * *} \\
(-0.274)\end{array}$ & $\begin{array}{c}0.005^{* * *} \\
(0.248)\end{array}$ & $\begin{array}{c}0.004^{* *} \\
(0.071)\end{array}$ & $\begin{array}{c}0.004 \\
(0.023)\end{array}$ & $\begin{array}{c}0.070 \\
(0.021)\end{array}$ & $\begin{array}{l}0.000^{* * *} \\
(-0.064)\end{array}$ & $\begin{array}{c}0.001 * * * \\
(0.044)\end{array}$ & 22,555 & 0.334 \\
\hline & $720 \mathrm{~m}$ & $\begin{array}{c}-0.016^{* * *} \\
(-0.333)\end{array}$ & $\begin{array}{c}-0.001^{* * *} \\
(-0.299)\end{array}$ & $\begin{array}{c}0.005^{* * *} \\
(0.202)\end{array}$ & $\begin{array}{c}0.006^{* *} \\
(0.089)\end{array}$ & $\begin{array}{c}0.003 \\
(0.039)\end{array}$ & $\begin{array}{c}0.193 \\
(0.050)\end{array}$ & $\begin{array}{l}0.000^{* * *} \\
(-0.151)\end{array}$ & $\begin{array}{c}0.002 * * \\
(0.048)\end{array}$ & $11,323.9$ & 0.362 \\
\hline & $960 \mathrm{~m}$ & $\begin{array}{c}-0.018^{* * *} \\
(-0.392)\end{array}$ & $\begin{array}{c}-0.001^{* * *} \\
(-0.325)\end{array}$ & $\begin{array}{c}0.005^{* * *} \\
(0.225)\end{array}$ & $\begin{array}{l}0.012 * * \\
(0.150)\end{array}$ & $\begin{array}{l}-0.001 \\
(0.012)\end{array}$ & $\begin{array}{c}0.084 \\
(0.020)\end{array}$ & $\begin{array}{c}0.000 \text { * } \\
(-0.064)\end{array}$ & $\begin{array}{l}0.002 * \\
(0.044)\end{array}$ & 6371.76 & 0.399 \\
\hline
\end{tabular}

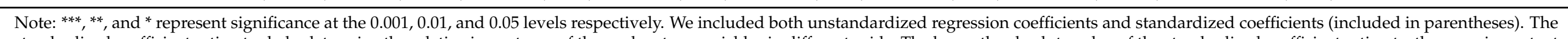

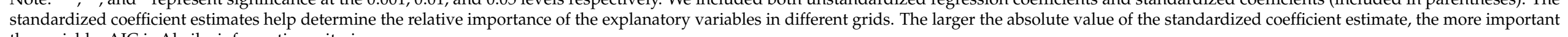
the variable. AIC is Akaike information criterion. 
Table 6. The results of spatial error models (SEM).

\begin{tabular}{|c|c|c|c|c|c|c|c|c|c|c|c|}
\hline Season & Scale(m) & PLAND & PD & ED & AI & AREA_MN & SHAPE_MN & Water_Distance & Population Density & AIC & $\mathbf{R}^{2}$ \\
\hline \multirow{4}{*}{ Summer } & $360 \mathrm{~m}$ & $\begin{array}{l}-0.035^{* * *} \\
(-0.269)\end{array}$ & $\begin{array}{l}-0.001^{* * *} \\
(-0.174)\end{array}$ & $\begin{array}{c}0.005^{* * *} \\
(0.089)\end{array}$ & $\begin{array}{c}0.008^{* * *} \\
(0.049)\end{array}$ & $\begin{array}{c}0.0422^{* * *} \\
(0.043)\end{array}$ & $\begin{array}{l}-0.009 \\
(0.000)\end{array}$ & $\begin{array}{c}0.000 * * * \\
(0.154)\end{array}$ & $\begin{array}{c}0.007^{* * * *} \\
(0.064)\end{array}$ & $55,629.1$ & 0.827 \\
\hline & $510 \mathrm{~m}$ & $\begin{array}{c}-0.049 * * * \\
(-0.380)\end{array}$ & $\begin{array}{c}-0.003^{* * *} \\
(-0.205)\end{array}$ & $\begin{array}{c}0.008^{* * *} \\
(0.146)\end{array}$ & $\begin{array}{l}0.006^{* *} \\
(0.033)\end{array}$ & $\begin{array}{l}0.022^{* *} \\
(0.044)\end{array}$ & $\begin{array}{c}-0.083 \\
(-0.009)\end{array}$ & $\begin{array}{c}0.000^{* * *} \\
(0.183)\end{array}$ & $\begin{array}{l}0.003 \text { * } \\
(0.034)\end{array}$ & $28,148.5$ & 0.845 \\
\hline & $720 \mathrm{~m}$ & $\begin{array}{c}-0.054^{* * *} \\
(-0.394)\end{array}$ & $\begin{array}{c}-0.001^{* * *} \\
(-0.236)\end{array}$ & $\begin{array}{c}0.008^{* * *} \\
(0.134)\end{array}$ & $\begin{array}{l}0.016^{* *} \\
(0.081)\end{array}$ & $\begin{array}{c}0.009 \\
(0.035)\end{array}$ & $\begin{array}{l}-0.022 \\
(0.002)\end{array}$ & $\begin{array}{c}0.000^{* * *} \\
(0.177)\end{array}$ & $\begin{array}{l}0.006 \text { * } \\
(0.059)\end{array}$ & $15,234.9$ & 0.763 \\
\hline & $960 \mathrm{~m}$ & $\begin{array}{l}-0.059 * * * \\
(-0.437)\end{array}$ & $\begin{array}{l}-0.002^{* * *} \\
(-0.281)\end{array}$ & $\begin{array}{c}0.012^{* * *} \\
(0.175)\end{array}$ & $\begin{array}{l}0.018^{* *} \\
(0.077)\end{array}$ & $\begin{array}{c}0.003 \\
(0.024)\end{array}$ & $\begin{array}{c}0.155 \\
(0.013)\end{array}$ & $\begin{array}{l}0.000 * \\
(0.162)\end{array}$ & $\begin{array}{l}0.006 \text { * } \\
(0.063)\end{array}$ & 8734 & 0.763 \\
\hline \multirow{4}{*}{$\begin{array}{l}\text { Transition } \\
\text { Season }\end{array}$} & $360 \mathrm{~m}$ & $\begin{array}{c}-0.016^{* * *} \\
(-0.218)\end{array}$ & $\begin{array}{l}-0.000^{* * *} \\
(-0.162)\end{array}$ & $\begin{array}{c}0.003^{* * *} \\
(0.093)\end{array}$ & $\begin{array}{c}0.005^{* * *} \\
(0.054)\end{array}$ & $\begin{array}{l}0.018^{* *} \\
(0.033)\end{array}$ & $\begin{array}{c}0.024 \\
(0.005)\end{array}$ & $\begin{array}{l}0.000^{* *} \\
(0.099)\end{array}$ & $\begin{array}{c}0.003^{* * *} \\
(0.059)\end{array}$ & $41,941.6$ & 0.830 \\
\hline & $510 \mathrm{~m}$ & $\begin{array}{c}-0.023^{* * *} \\
(-0.318)\end{array}$ & $\begin{array}{c}-0.002 * * * \\
(-0.186)\end{array}$ & $\begin{array}{c}0.005^{* * *} \\
(0.154)\end{array}$ & $\begin{array}{c}0.0038^{* *} \\
(0.040)\end{array}$ & $\begin{array}{l}0.011^{* *} \\
(0.040)\end{array}$ & $\begin{array}{c}-0.032 \\
(-0.006)\end{array}$ & $\begin{array}{c}0.000 * * * \\
(0.119)\end{array}$ & $\begin{array}{l}0.0012 \text { * } \\
(0.033)\end{array}$ & $21,081.8$ & 0.844 \\
\hline & $720 \mathrm{~m}$ & $\begin{array}{l}0.026^{* * *} \\
(-0.338)\end{array}$ & $\begin{array}{c}-0.000^{* * *} \\
(-0.214)\end{array}$ & $\begin{array}{c}0.005^{* * *} \\
(0.144)\end{array}$ & $\begin{array}{c}0.008^{* * *} \\
(0.076)\end{array}$ & $\begin{array}{c}0.003 \\
(0.024)\end{array}$ & $\begin{array}{c}0.077 \\
(0.012)\end{array}$ & $\begin{array}{c}0.000 \\
(0.039)\end{array}$ & $\begin{array}{l}0.003 \text { * } \\
(0.050)\end{array}$ & $11,714.4$ & 0.759 \\
\hline & $960 \mathrm{~m}$ & $\begin{array}{c}-0.029 * * * \\
(-0.397)\end{array}$ & $\begin{array}{c}-0.000^{* * *} \\
(-0.239)\end{array}$ & $\begin{array}{c}0.007^{* * *} \\
(0.188)\end{array}$ & $\begin{array}{c}0.014^{* * *} \\
(0.106)\end{array}$ & $\begin{array}{c}-0.000 \\
(-0.005)\end{array}$ & $\begin{array}{c}0.057 \\
(0.009) \\
\end{array}$ & $\begin{array}{c}0.000 \\
(0.096) \\
\end{array}$ & $\begin{array}{c}0.003 \\
(0.048) \\
\end{array}$ & 6637 & 0.767 \\
\hline \multirow{4}{*}{ Winter } & $360 \mathrm{~m}$ & $\begin{array}{c}-0.009^{* * *} \\
(-0.207)\end{array}$ & $\begin{array}{c}-0.000^{* * *} \\
(-0.217)\end{array}$ & $\begin{array}{c}0.002 * * * \\
(0.093)\end{array}$ & $\begin{array}{c}0.003^{* * * *} \\
(0.057)\end{array}$ & $\begin{array}{l}0.014 \text { ** } \\
(0.043)\end{array}$ & $\begin{array}{c}-0.012 \\
(-0.004)\end{array}$ & $\begin{array}{c}-0.000^{* * * *} \\
(-0.139)\end{array}$ & $\begin{array}{l}0.002 * * \\
(0.046)\end{array}$ & 36,329 & 0.711 \\
\hline & $510 \mathrm{~m}$ & $\begin{array}{l}-0.014^{* * *} \\
(-0.326)\end{array}$ & $\begin{array}{l}-0.001^{* * *} \\
(-0.257)\end{array}$ & $\begin{array}{c}0.003^{* * *} \\
(0.163)\end{array}$ & $\begin{array}{l}0.003 \text { ** } \\
(0.054)\end{array}$ & $\begin{array}{c}0.010^{* * *} \\
(0.062)\end{array}$ & $\begin{array}{c}-0.077 \\
(-0.023)\end{array}$ & $\begin{array}{c}0.000 \\
(-0.016)\end{array}$ & $\begin{array}{c}0.000 \\
(0.028)\end{array}$ & $17,549.6$ & 0.749 \\
\hline & $720 \mathrm{~m}$ & $\begin{array}{l}-0.013^{* * * *} \\
(-0.284)\end{array}$ & $\begin{array}{l}-0.000^{* * *} \\
(-0.289)\end{array}$ & $\begin{array}{c}0.002^{* * *} \\
(0.128)\end{array}$ & $\begin{array}{l}0.006^{* *} \\
(0.079)\end{array}$ & $\begin{array}{l}0.005 \text { * } \\
(0.053)\end{array}$ & $\begin{array}{c}-0.028 \\
(-0.007)\end{array}$ & $\begin{array}{l}-0.000^{* * * *} \\
(-0.153)\end{array}$ & $\begin{array}{c}0.001 \\
(0.042)\end{array}$ & 9942.35 & 0.639 \\
\hline & $960 \mathrm{~m}$ & $\begin{array}{l}-0.016^{* * * *} \\
(-0.336)\end{array}$ & $\begin{array}{l}-0.000^{* * *} \\
(-0.319)\end{array}$ & $\begin{array}{c}0.004^{* * *} \\
(0.166)\end{array}$ & $\begin{array}{c}0.007^{* * *} \\
(0.091)\end{array}$ & $\begin{array}{c}0.001 \\
(0.031)\end{array}$ & $\begin{array}{c}-0.029 \\
(-0.007)\end{array}$ & $\begin{array}{l}-0.000 \\
(-0.025)\end{array}$ & $\begin{array}{c}0.001 \\
(0.047)\end{array}$ & 5439.88 & 0.693 \\
\hline
\end{tabular}

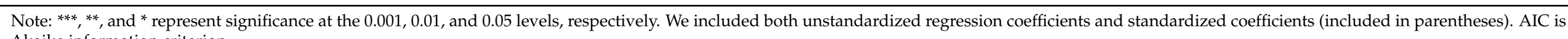
Akaike information criterion. 


\section{Discussion}

\subsection{Spatial Variation of LST}

Urban LST decreases with the change from summer to winter. Owing to the characteristics of urban development in Fuzhou, the suburbs are basically surrounded by mountains and less developed, which is why the distribution characteristics of the high-temperature areas across the whole study area are obvious and $\mathrm{H}-\mathrm{H}$ accumulation is mainly distributed in the urban center where the population is concentrated. Urban expansion leads to the continuous reduction of green space and the continuous expansion of construction land, man-made emissions, etc., resulting in high LST. L-L aggregation is mainly distributed around the suburbs. With the decrease in LST, the aggregation degree of $\mathrm{H}-\mathrm{H}$ decreased, while the L-L aggregation in the suburbs increased significantly.

\subsection{Differences in the Impact of UGS on UHI Mitigation}

Our OLS analysis showed that the indexes which contributed greatly to the cooling of LST under the standardized coefficient are PLAND and PD. This supports the claim that PLAND has great explanatory significance for cooling [55]. ED, AI, and population density also had significant effects on LST. At the same time, the effect of model fitting increased with an increase in the grid scale.

The results of the index analysis by the SEM model were slightly different from those of the OLS model. The coefficient of determination $\left(R^{2}\right)$ for each variable at the $510 \mathrm{~m}$ grid scale is higher than the other three scales of this study. With an increase in scale, the value of each index coefficient increases. The landscape metrics PLAND and PD of green space showed an obvious negative correlation with LST, which is consistent with the research results of $[40,55]$. This shows that an increase in green space area, a larger patch area, and more patch quantity can reduce LST, given that green space can produce cold island effects through evapotranspiration, as well as shade to prevent the surface from being directly heated by the sun [56]. At the same time, the more aggregated the patch area, the better the connectivity and interaction between vegetation, and the better the cooling effect on the area [57]. However, the results of ED contradicted some previous studies. LST was found to decrease with an increase in the complexity of plant shape and edge density, probably because the shape complexity of edge density can increase the area of shadow provided by plants and reduce LST [40]. Although the patch edge density in Fuzhou was high, there were many small patches in Fuzhou and the green space distribution was relatively scattered, which weakened the cooling capacity of the green space and reduced the cooling effect [58-60]. Several studies have pointed out that population density is an important reason for the rise in LST. The more densely populated an area is, the more anthropogenic heat emissions there are, and the higher the UHI [34,61]. The heat island effect is more pronounced closer to the urban center. In the summer and transition seasons, the effect of population density on LST was positively correlated, but the correlation was not obvious in winter.

At the same time, different seasons have a significant impact on indicators. The nearest distance to the water was positively correlated with LST in the summer and transition seasons, but not in winter. It may be that rivers are scattered, mainly distributed around roads and urban areas, and are seriously disturbed by human factors. This shows that the distance and area of the water from the urban area are different, the degree of impact of human activities is different, and the impact on LST is different in different seasons. Because of the low temperature in winter, the temperature difference between the water body and the surface decreases, so the factors affecting LST will also decrease and the cooling effect will not be so obvious [33,62]. Overall, the research shows that the impact of the index in summer and transition season is higher than that in winter; in summer, the heat brought by the reduction of thermal radiation and evaporation is greater than that in winter, the temperature in winter is low, the impact of vegetation on LST is reduced [62], and the amount of solar thermal radiation is small $[36,62,63]$. 


\subsection{UHI Mitigation Implications by Urban Greening}

Our findings help planners to implement differentiated UGS management strategies for LST alleviation in specific regions. From the analysis, it is clear that increasing the UGS coverage is the most effective way to promote cooling effects. However, with the acceleration of urbanization in Fuzhou, green space resources are gradually being reduced, while the spread of impervious surfaces has also reduced the aggregation of green space patches and dispersed them. Under limited circumstances, it is difficult to conduct greening in large areas, thus optimizing space allocation and improving space utilization, such as increasing roof greening and pocket parks [20] in undeveloped urban suburbs, is necessary. During the construction process, the patch areas of green space can be increased, and a certain scale of parks and green spaces can be built to improve the evapotranspiration of plants and reduce the development intensity of the city and the aggregation of buildings. With the urbanization of Fuzhou in recent years, a large number of UGS have been reduced, which have resulted in many scattered patches [18]. The edge density of these patches is large, which results in a low cooling effect. Therefore, improving the connectivity between patches and reducing the fragmentation of patches can improve the mitigation effect of green spaces on UHIs. At the same time, Fuzhou has a rich network of urban waterways since it has a significant effect on reducing LST. With the optimization and rational use of the water system and the protection of existing wetlands from damage, we can alleviate the negative impact of the thermal environment $[32,64]$.

\subsection{Limitations and Future Research}

The changes in urban ecosystems and land use/land cover caused by accelerated urbanization have largely exacerbated the UHI effect [20]. Combining land use data from multiple years can better identify the changing patterns of LST; this study only used one year's worth of data to analyze the spatial characteristics of green space and LST in Fuzhou. Meanwhile, there are many factors affecting LST, and the study failed to comprehensively analyze the interactions between multiple LST influencing elements. By analyzing the LST temperature changes across different years using the long-time series and multi-cycle data analysis in combination with different indicators in the future, the UHI effect can be analyzed more comprehensively. Incorporating it with the above analysis in future studies can also help us study and alleviate the heat island effects in Fuzhou more comprehensively.

\section{Conclusions}

Taking Fuzhou as the study area, this paper used a bivariate spatial autocorrelation and spatial autoregression model to analyze the spatial relationship between different green landscape elements and LST in different seasons from multiple grid scales. The results showed that the percentage of landscape and patch density were negatively correlated with LST, while edge density and aggregation index were positively correlated with LST. Mean patch shape index had no correlation. At the same time, the dominant factors affecting LST differed according to the season. Distance to the water body and population density had positive impact on LST during the summer, but the correlation weakened in the transition season and winter. With the decrease of seasonal temperature, the explanatory effect of each index on LST decreased accordingly. Because the factors affecting LST in the winter differed from the other seasons, this indicates that more factors need to be considered in the analysis of LST, and mitigation measures need to be taken for different seasons. At the same time, it was found that the coefficient of the spatial error model was lower than that of the OLS regression model, indicating that SEM considers the spatial autocorrelation of each index. The fitting effect of SEM is better than that of OLS, which proves it can better explain the spatial relationship between the greenspace landscape pattern and LST. This study also analyzed the impact of landscape indicators on LST in different seasons at different grid scales to identify seasonal changes that can promote development and guide urban planning, and ultimately reduce the UHI effect. 
Author Contributions: Conceptualization, J.L. and K.Y.; methodology, L.Y.; software, L.Y.; validation, L.Y., L.L. (Lili Lin) and L.L. (Lingchen Lin); formal analysis, L.Y. and L.L. (Lingchen Lin); investigation, L.Y.; resources, L.Y.; data curation, Y.L. and J.A.; writing-original draft preparation, L.Y.; writingreview and editing, L.Y.; visualization, L.Y.; supervision, K.Y.; project administration, J.L.; funding acquisition, J.L. and K.Y. All authors have read and agreed to the published version of the manuscript.

Funding: This research was funded by Fujian Province Key Laboratory of Geographic Information Technology and Resource Optimization Construction Project, grant number (PTJH17014).

Institutional Review Board Statement: Not applicable.

Informed Consent Statement: Not applicable.

Data Availability Statement: The data that support the findings of this study are available from the author upon reasonable request.

Acknowledgments: We sincerely thank the editor and anonymous reviewers for their valuable comments and suggestions to improve the quality of this paper.

Conflicts of Interest: The authors declare no conflict of interest.

\section{Appendix A}

Local indicators of spatial association (LISA) at different grid scales in the study area.

(a)
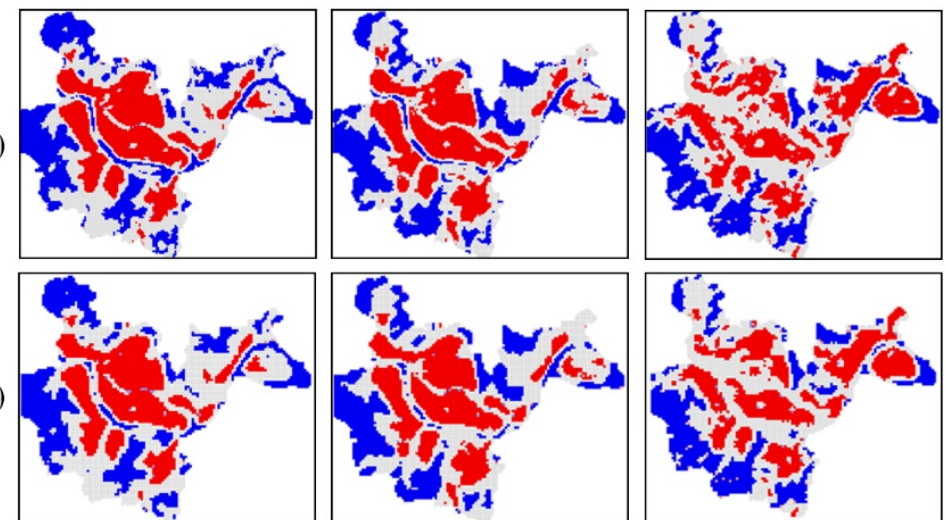

(c)
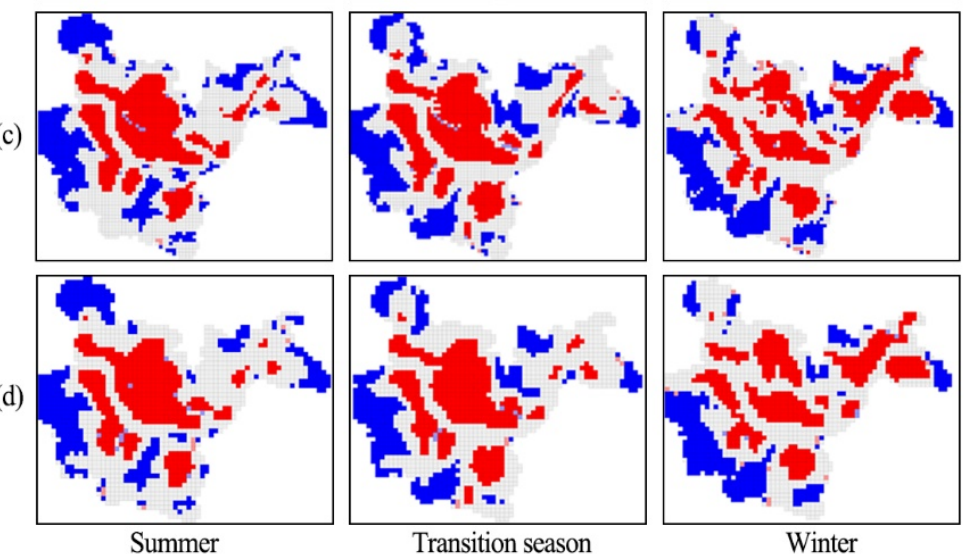

Not significant $\square$ High-high cluster

Transition season

Winter

Figure A1. (a) $360 \mathrm{~m} \times 360 \mathrm{~m}$; (b) $510 \mathrm{~m} \times 510 \mathrm{~m}$; (c) $720 \mathrm{~m} \times 720 \mathrm{~m}$; (d) $960 \mathrm{~m} \times 960 \mathrm{~m}$. (1) High- high means spatial clustering of similarly high values, (2) low-low means spatial clustering of similarly low values, (3) low-high cluster means low values surrounded by high neighboring values, and (4) high-low cluster means high values surrounded by low values. (5) no significant value. 


\section{Appendix A}

Table A1. Lagrange multiplier (LM) diagnostics for spatial dependence.

\begin{tabular}{|c|c|c|c|c|c|c|c|}
\hline \multirow[b]{2}{*}{ Scale (m) } & & \multicolumn{2}{|l|}{ Value } & \multicolumn{3}{|c|}{$p$-Value } & \multirow[b]{2}{*}{ Winter } \\
\hline & & Summer & $\begin{array}{c}\text { Transition } \\
\text { Season }\end{array}$ & Winter & Summer & $\begin{array}{c}\text { Transition } \\
\text { Season }\end{array}$ & \\
\hline \multirow[t]{5}{*}{$360 \mathrm{~m}$} & LM (SLM) & $17,669.722$ & $17,554.956$ & $14,749.657$ & 0.000 & 0.000 & 0.000 \\
\hline & Robust LM (SLM) & 751.682 & 817.425 & 335.424 & 0.000 & 0.000 & 0.000 \\
\hline & LM (SEM) & $18,289.119$ & $17,995.990$ & $15,079.633$ & 0.000 & 0.000 & 0.000 \\
\hline & Robust LM (SEM) & 1371.078 & 1258.459 & 665.401 & 0.000 & 0.000 & 0.000 \\
\hline & Moran's I (error) & 0.638 & 0.633 & 0.576 & 0.000 & 0.000 & 0.000 \\
\hline \multirow[t]{5}{*}{$510 \mathrm{~m}$} & LM (SLM) & 8980.604 & 8785.118 & 8081.876 & 0.000 & 0.000 & 0.000 \\
\hline & Robust LM (SLM) & 315.210 & 375.142 & 134.112 & 0.000 & 0.000 & 0.000 \\
\hline & LM (SEM) & 9733.919 & 9383.335 & 8577.889 & 0.000 & 0.000 & 0.000 \\
\hline & Robust LM (SEM) & 1068.525 & 973.335 & 630125 & 0.000 & 0.000 & 0.000 \\
\hline & Moran's I (error) & 0.646 & 0.634 & 0.606 & 0.000 & 0.000 & 0.000 \\
\hline \multirow[t]{5}{*}{$720 \mathrm{~m}$} & LM (SLM) & 2777.740 & 2600.889 & 2244.589 & 0.000 & 0.000 & 0.000 \\
\hline & Robust LM (SLM) & 164.529 & 165.802 & 62.053 & 0.000 & 0.000 & 0.000 \\
\hline & LM (SEM) & 2892.608 & 2658.432 & 2314.228 & 0.000 & 0.000 & 0.000 \\
\hline & Robust LM (SEM) & 279.137 & 223.345 & 131.692 & 0.000 & 0.000 & 0.000 \\
\hline & Moran's I (error) & 0.506 & 0.485 & 0.453 & 0.000 & 0.000 & 0.000 \\
\hline \multirow[t]{5}{*}{$960 \mathrm{~m}$} & LM (SLM) & 1229.250 & 1196.510 & 1335.168 & 0.000 & 0.000 & 0.000 \\
\hline & Robust LM (SLM) & 52.147 & 77.669 & 38.198 & 0.000 & 0.000 & 0.000 \\
\hline & LM (SEM) & 1393.353 & 1308.945 & 1443.972 & 0.000 & 0.000 & 0.000 \\
\hline & Robust LM (SEM) & 216.250 & 190.104 & 147.002 & 0.000 & 0.000 & 0.000 \\
\hline & Moran's I (error) & 0.466 & 0.451 & 0.474 & 0.000 & 0.000 & 0.000 \\
\hline
\end{tabular}

Note: $p$-value is the probability of observing an event at least as extreme as the test statistic.

\section{References}

1. Oke, T.R. The energetic basis of the urban heat island. Q. J. R. Meteorol. Soc. 1982, 108, 1-24. [CrossRef]

2. Morris, K.I.; Chan, A.; Morris, K.J.K.; Ooi, M.C.G.; Oozeer, M.Y.; Abakr, Y.A.; Nadzir, M.S.M.; Mohammed, I.Y.; Al-Qrimli, H.F. Impact of urbanization level on the interactions of urban area, the urban climate, and human thermal comfort. Appl. Geogr. 2017, 79, 50-72. [CrossRef]

3. Li, H.; Meier, F.; Lee, X.; Chakraborty, T.; Liu, J.; Schaap, M.; Sodoudi, S. Interaction between urban heat island and urban pollution island during summer in Berlin. Sci. Total Environ. 2018, 636, 818-828. [PubMed]

4. Jochner, S.; Menzel, A. Urban phenological studies-Past, present, future. Environ. Pollut. 2015, 203, 250-261. [CrossRef]

5. Zhou, D.; Zhao, S.; Zhang, L.; Liu, S. Remotely sensed assessment of urbanization effects on vegetation phenology in China's 32 major cities. Remote. Sens. Environ. 2016, 176, 272-281. [CrossRef]

6. Grimm, N.B.; Faeth, S.H.; Golubiewski, N.E.; Redman, C.L.; Wu, J.; Bai, X.; Briggs, J.M. Global change and the ecology of cities. Science 2008, 319, 756-760. [CrossRef]

7. Ingole, V.; Marí-Dell'Olmo, M.; Deluca, A.; Borrell, C.; Basagaa, X. Spatial Variability of Heat-Related Mortality in Barcelona from 1992-2015: A Case Crossover Study Design. Int. J. Environ. Res. Public Health 2020, 17, 2553. [CrossRef] [PubMed]

8. Kim, S.W.; Brown, R.D. Urban heat island (UHI) variations within a city boundary: A systematic literature review. Renew. Sustain. Energy Rev. 2021, 148, 111256. [CrossRef]

9. $\mathrm{Xu}, \mathrm{H}$.Q. Quantitative analysis on the relationship of urban impervious surface with other components of the urban ecosystem. Acta Ecol. Sin. 2009, 29, 2456-2462.

10. Yu, Z.; Yao, Y.; Yang, G.; Wang, X.; Vejre, H. Spatiotemporal patterns and characteristics of remotely sensed region heat islands during the rapid urbanization (1995-2015) of Southern China. Sci. Total Environ. 2019, 674, 242-254. [CrossRef]

11. Shukla, A.; Jain, K. Analyzing the impact of changing landscape pattern and dynamics on land surface temperature in Lucknow city, India. Urban For. Urban Green. 2021, 58, 126877. [CrossRef]

12. Estoque, R.C.; Murayama, Y.; Myint, S.W. Effects of landscape composition and pattern on land surface temperature: An urban heat island study in the megacities of Southeast Asia. Sci. Total Environ. 2017, 577, 349-359. [CrossRef]

13. Chrysoulakis, N.; Feigenwinter, C.; Triantakonstantis, D.; Penyevskiy, I.; Tal, A.; Parlow, E.; Fleishman, G.; Düzgün, S.; Esch, T.; Marconcini, M. A Conceptual List of Indicators for Urban Planning and Management Based on Earth Observation. ISPRS Int. J. Geo-Inf. 2014, 3, 980-1002. [CrossRef] 
14. Mitraka, Z.; Chrysoulakis, N.; Doxani, G.; Del Frate, F.; Berger, M. Urban Surface Temperature Time Series Estimation at the Local Scale by Spatial-Spectral Unmixing of Satellite Observations. Remote Sens. 2015, 7, 4139-4156. [CrossRef]

15. Fidani, S.; Daliakopoulos, I.; Manios, T.; Grillakis, M.; Charalampopoulou, V.; Nektarios, P. Evaluating the Effect of Green Infrastructure in Mitigating the Urban Heat Island Effect Using Remote Sensing. In Proceedings of the EGU General Assembly 2021, online, 19-30 April 2021. [CrossRef]

16. Jiang, Y.; Fu, P.; Weng, Q. Assessing the Impacts of Urbanization-Associated Land Use/Cover Change on Land Surface Temperature and Surface Moisture: A Case Study in the Midwestern United States. Remote Sens. 2015, 7, 4880-4898. [CrossRef]

17. Xie, Q.; Sun, Q. Monitoring thermal environment deterioration and its dynamic response to urban expansion in Wuhan, China. Urban Clim. 2021, 39, 100932. [CrossRef]

18. Cai, Y.; Chen, Y.; Tong, C. Spatiotemporal evolution of urban green space and its impact on the urban thermal environment based on remote sensing data: A case study of Fuzhou City, China. Urban For. Urban Green. 2019, 41, 333-343. [CrossRef]

19. Oliveira, S.; Andrade, H.; Vaz, T. The cooling effect of green spaces as a contribution to the mitigation of urban heat: A case study in Lisbon. Build. Environ. 2011, 46, 2186-2194. [CrossRef]

20. Zhou, W.; Huang, G.; Cadenasso, M.L. Does spatial configuration matter? Understanding the effects of land cover pattern on land surface temperature in urban landscapes. Landsc. Urban Plan. 2011, 102, 54-63.

21. Liu, G.; Zhang, Q.; Li, G.; Doronzo, D.M. Response of land cover types to land surface temperature derived from Landsat-5 TM in Nanjing Metropolitan Region, China. Environ. Earth Sci. 2016, 75, 1381-1386. [CrossRef]

22. Asgarian, A.; Amiri, B.J.; Sakieh, Y. Assessing the effect of green cover spatial patterns on urban land surface temperature using landscape metrics approach. Urban Ecosyst. 2015, 18, 209-222. [CrossRef]

23. Peng, J.; Hu, Y.; Dong, J.; Liu, Q.; Liu, Y. Quantifying spatial morphology and connectivity of urban heat islands in a megacity: A radius approach. Sci. Total Environ. 2020, 714, 136792. [CrossRef]

24. Lv, H.; Yang, Y.; Zhang, D.; Du, H.; Zhang, J.; Wang, W.; He, X. Perimeter-area ratio effects of urbanization intensity on forest characteristics, landscape patterns and their associations in Harbin City, Northeast China. Urban Ecosyst. 2019, 22, 631-642. [CrossRef]

25. Maimaitiyiming, M.; Ghulam, A.; Tiyip, T.; Pla, F.; Latorre-Carmona, P.; Halik, Ü.; Sawut, M.; Caetano, M. Effects of green space spatial pattern on land surface temperature: Implications for sustainable urban planning and climate change adaptation. ISPRS $J$ Photogramm. 2014, 89, 59-66. [CrossRef]

26. Richards, D.R.; Fung, T.K.; Belcher, R.N.; Edwards, P.J. Differential air temperature cooling performance of urban vegetation types in the tropics. Urban For. Urban Green. 2020, 50, 126651. [CrossRef]

27. Rakoto, P.Y.; Deilami, K.; Hurley, J.; Amati, M.; Sun, Q.C. Revisiting the cooling effects of urban greening: Planning implications of vegetation types and spatial configuration. Urban For. Urban Green. 2021, 64, 127266. [CrossRef]

28. Li, J.; Song, C.; Cao, L.; Zhu, F.; Meng, X.; Wu, J. Impacts of landscape structure on surface urban heat islands: A case study of Shanghai, China. Remote Sens. Environ. 2011, 115, 3249-3263. [CrossRef]

29. Ke, X.; Men, H.; Zhou, T.; Li, Z.; Zhu, F. Variance of the impact of urban green space on the urban heat island effect among different urban functional zones: A case study in Wuhan. Urban For. Urban Green. 2021, 62, 127159. [CrossRef]

30. Li, X.; Zhou, W.; Ouyang, Z. Relationship between land surface temperature and spatial pattern of greenspace: What are the effects of spatial resolution? Landsc. Urban Plan. 2013, 114, 1-8. [CrossRef]

31. Hou, H.; Estoque, R.C. Detecting Cooling Effect of Landscape from Composition and Configuration: An Urban Heat Island Study on Hangzhou. Urban For. Urban Green. 2020, 53, 126719. [CrossRef]

32. Du, J.; Xiang, X.; Zhao, B.; Zhou, H. Impact of urban expansion on land surface temperature in Fuzhou, China using Landsat imagery. Sustain. Cities Soc. 2020, 61, 102346. [CrossRef]

33. Peng, J.; Jia, J.; Liu, Y.; Li, H.; Wu, J. Seasonal contrast of the dominant factors for spatial distribution of land surface temperature in urban areas. Remote Sens. Environ. 2018, 215, 255-267. [CrossRef]

34. Geng, S.; Yang, L.; Sun, Z.; Wang, Z.; Qian, J.; Jiang, C.; Wen, M. Spatiotemporal patterns and driving forces of remotely sensed urban agglomeration heat islands in South China. Sci. Total Environ. 2021, 800, 149499. [CrossRef] [PubMed]

35. Feng, L.; Zhao, M.; Zhou, Y.; Zhu, L.; Tian, H. The seasonal and annual impacts of landscape patterns on the urban thermal comfort using Landsat. Ecol. Indic. 2020, 110, 105798. [CrossRef]

36. Lu, Y.; Yue, W.; Liu, Y.; Huang, Y. Investigating the spatiotemporal non-stationary relationships between urban spatial form and land surface temperature: A case study of Wuhan, China. Sustain. Cities Soc. 2021, 72, 103070. [CrossRef]

37. Fu, B.; Wang, Y.; Campbell, A.; Li, Y.; Zhang, B.; Yin, S.; Xing, Z.; Jin, X. Comparison of object-based and pixel-based Random Forest algorithm for wetland vegetation mapping using high spatial resolution GF-1 and SAR data. Ecol. Indic. 2017, 73, 105-117. [CrossRef]

38. Peng, J.; Wang, Y.; Zhang, Y.; Wu, J.; Li, W.; Li, Y. Evaluating the effectiveness of landscape metrics in quantifying spatial patterns. Ecol. Indic. 2010, 10, 217-223. [CrossRef]

39. Zhang, Y.; Balzter, H.; Zou, C.; Xu, H.; Tang, F. Characterizing bi-temporal patterns of land surface temperature using landscape metrics based on sub-pixel classifications from Landsat TM/ETM+. Int. J. Appl. Earth Obs. 2015, 42, 87-96. [CrossRef]

40. Li, X.; Zhou, W.; Ouyang, Z.; Xu, W.; Zheng, H. Spatial pattern of greenspace affects land surface temperature: Evidence from the heavily urbanized Beijing metropolitan area, China. Landsc. Ecol. 2012, 27, 887-898. [CrossRef] 
41. Liu, H.; Weng, Q. Scaling Effect on the Relationship between Landscape Pattern and Land Surface Temperature. Photogramm. Eng. Remote. Sens. 2009, 75, 291-304. [CrossRef]

42. Guo, G.; Zhou, X.; Wu, Z.; Xiao, R.; Chen, Y. Characterizing the impact of urban morphology heterogeneity on land surface temperature in Guangzhou, China. Environ. Model. Softw. 2016, 84, 427-439. [CrossRef]

43. Yang, C.; He, X.; Wang, R.; Yan, F.; Lingxue, Y.; Bu, K.; Yang, J.; Chang, L.; Zhang, S. The Effect of Urban Green Spaces on the Urban Thermal Environment and Its Seasonal Variations. Forests 2017, 8, 153. [CrossRef]

44. Song, J.; Du, S.; Feng, X.; Guo, L. The relationships between landscape compositions and land surface temperature: Quantifying their resolution sensitivity with spatial regression models. Landsc. Urban Plan. 2014, 123, 145-157. [CrossRef]

45. Tan, M.; Li, X. Quantifying the effects of settlement size on urban heat islands in fairly uniform geographic areas. Habitat Int. 2015, 49, 100-106. [CrossRef]

46. Yao, L.; Sun, S.; Song, C.; Li, J.; Xu, W.; Xu, Y. Understanding the spatiotemporal pattern of the urban heat island footprint in the context of urbanization, a case study in Beijing, China. Appl. Geogr. 2021, 133, 102496. [CrossRef]

47. Liang, Z.; Huang, J.; Wang, Y.; Wei, F.; Wu, S.; Jiang, H.; Zhang, X.; Li, S. The mediating effect of air pollution in the impacts of urban form on nighttime urban heat island intensity. Sustain. Cities Soc. 2021, 74, 102985. [CrossRef]

48. Mcgarigal, K.S.; Cushman, S.A.; Neel, M.C.; Ene, E. FRAGSTATS: Spatial Pattern Analysis Program for Categorical Maps. 2002. Available online: www.umass.edu/landeco/research/fragstats/fragstats (accessed on 15 September 2020).

49. Getis, A. Spatial Autocorrelation: A Primer. Econ. Geogr. 1988, 64, 88. [CrossRef]

50. Chi, G.; Zhu, J. Spatial Regression Models for Demographic Analysis. Popul. Res. Policy Rev. 2008, 27, 17-42. [CrossRef]

51. Scott, L.M.; Janikas, M.V. Handbook of Applied Spatial Analysis; Springer: Berlin/Heidelberg, Germany, 2010.

52. Anselin, L. Local Indicators of Spatial Association-ISA. Geogr. Anal. 2010, 27, 93-115. [CrossRef]

53. Tian, X.; Deng, Y.; Wargocki, P.; Liu, W. Effects of increased activity level on physiological and subjective responses at different high temperatures. Build. Environ. 2021, 201, 108011. [CrossRef]

54. Shen, Z.; Zeng, J.; Liang, C. Spatial relationship of greenspace landscape pattern with land surface temperature in three cities of southern Fujian. Chin. J. Ecol. 2020, 39, 245-253.

55. Chen, A.; Yao, L.; Sun, R.; Chen, L. How many metrics are required to identify the effects of the landscape pattern on land surface temperature? Ecol. Indic. 2014, 45, 424-433. [CrossRef]

56. Zhou, W.; Wang, J.; Cadenasso, M.L. Effects of the spatial configuration of trees on urban heat mitigation: A comparative study. Remote Sens. Environ. 2017, 195, 1-12. [CrossRef]

57. Yang, J.; Sun, J.; Ge, Q.; Li, X. Assessing the impacts of urbanization-associated green space on urban land surface temperature: A case study of Dalian, China. Urban For. Urban Green. 2017, 22, 1-10. [CrossRef]

58. Kong, F.; Yin, H.; James, P.; Hutyra, L.R.; He, H.S. Effects of spatial pattern of greenspace on urban cooling in a large metropolitan area of eastern China. Landsc. Urban Plan. 2014, 128, 35-47. [CrossRef]

59. Guo, G.; Wu, Z.; Chen, Y. Complex mechanisms linking land surface temperature to greenspace spatial patterns: Evidence from four southeastern Chinese cities. Sci. Total Environ. 2019, 674, 77-87. [CrossRef] [PubMed]

60. Zhang, X.; Zhong, T.; Feng, X.; Wang, K. Estimation of the relationship between vegetation patches and urban land surface temperature with remote sensing. Int. J. Remote Sens. 2009, 30, 2105-2118. [CrossRef]

61. Zhou, D.; Zhao, S.; Liu, S.; Zhang, L.; Zhu, C. Surface urban heat island in China's 32 major cities: Spatial patterns and drivers. Remote Sens. Environ. 2014, 152, 51-61. [CrossRef]

62. $\mathrm{Wu}, \mathrm{W}$; $\mathrm{Li}, \mathrm{L} . ; \mathrm{Li}, \mathrm{C}$. Seasonal variation in the effects of urban environmental factors on land surface temperature in a winter city. J. Clean. Prod. 2021, 299, 126897. [CrossRef]

63. Xiang, Y.; Huang, C.; Huang, X.; Zhou, Z.; Wang, X. Seasonal variations of the dominant factors for spatial heterogeneity and time inconsistency of land surface temperature in an urban agglomeration of central China. Sustain. Cities Soc. 2021, 75, 103285. [CrossRef]

64. Cai, Z.; Han, G.; Chen, M. Do water bodies play an important role in the relationship between urban form and land surface temperature? Sustain. Cities Soc. 2018, 39, 487-498. [CrossRef] 